AperTO - Archivio Istituzionale Open Access dell'Università di Torino

Formation of highly oxygenated multifunctional compounds from cross-reactions of carbonyl compounds in the atmospheric aqueous phase

This is a pre print version of the following article:

Original Citation:

Availability:

This version is available http://hdl.handle.net/2318/1724298

since 2020-01-21T15:45:36Z

Published version:

DOI:10.1016/j.atmosenv.2019.117046

Terms of use:

Open Access

Anyone can freely access the full text of works made available as "Open Access". Works made available under a Creative Commons license can be used according to the terms and conditions of said license. Use of all other works requires consent of the right holder (author or publisher) if not exempted from copyright protection by the applicable law. 


\section{Formation of Highly Oxygenated Multifunctional Compounds from Cross-reactions of Carbonyl Compounds in the Atmospheric Aqueous Phase}

Majda Mekic ${ }^{1,2}$, Jiangping Liu ${ }^{1,2}$, Zhou Wentao ${ }^{1,2}$, Gwendal Loisel ${ }^{1}$, Jing Cai ${ }^{1,2}$, Tan $\mathrm{He}^{1,2}$, Bin Jiang $^{1}$, Zhiqiang $\mathrm{Yu}^{1}$, Yannis G. Lazarou ${ }^{3}, \mathrm{Xue} \mathrm{Li}^{4}$, Marcello Brigante ${ }^{5}$, Davide Vione ${ }^{6}$, Sasho Gligorovski $^{1^{*}}$

${ }^{1}$ State Key Laboratory of Organic Geochemistry, Guangzhou Institute of Geochemistry, Chinese Academy of Sciences, Guangzhou 510 640, China

${ }^{2}$ University of Chinese Academy of Sciences, Beijing 10069, China

${ }^{3}$ Institute of Nanoscience and Nanotechnology, National Center for Scientific Research

"Demokritos", GR-15341 Agia Paraskevi, Greece

${ }^{4}$ Institute of Mass Spectrometry and Atmospheric Environment, Jinan University, Guangzhou 510632, China

${ }^{5}$ Université Clermont Auvergne, CNRS, SIGMA Clermont, Institut de Chimie de ClermontFerrand, F-63000 Clermont-Ferrand, France

${ }^{6}$ Dipartimento di Chimica, Università degli Studi di Torino, Via Pietro Giuria 5, 10125 Torino, Italy

*Corresponding author: gligorovski@gig.ac.cn 


\section{Abstract}

There is increasing evidence that aqueous-phase atmospheric chemistry is an important source of secondary organic aerosols (SOA), but this chemistry is currently not adequately represented in atmospheric models due to the missing information on most products. The main focus of this study is to provide molecular-level insight into the photosensitized reaction mechanism of pyruvic acid (PA) alone in the atmospheric aqueous phase, and of mixtures of PA with glyoxal (GL), a typical and widely occurring carbonyl compound. With two ultrahigh resolution mass spectrometers, Orbitrap and FT-ICR-MS, a broad and complex spectrum of organic products were unambiguously identified. The detected formation of oligomers illustrates the progression from $\mathrm{C}_{3}$ to $\mathrm{C}_{20}$ molecules through direct PA photolysis and irradiation of PA + GL. The performed $a b$-initio calculations indicate that cross-reactions (i.e., PA + GL) are more likely than self-reactions (i.e., PA alone) in clouds and aerosol deliquescent particles. Hence, this result implies that photosensitizers like PA can initiate the transformation of common organic cloud constituents like GL into oligomers. These oligomeric products that are formed in significant amount could potentially impact optical and cloud-forming properties of aerosols, especially if they partition to the aerosol surface. 


\section{INTRODUCTION}

The aqueous-phase chemistry of organic compounds in the atmosphere is often dominated by photochemical processes driven by the hydroxyl radical $(\mathrm{OH}){ }^{1-3}$ Recently, Ervens et al. ${ }^{4}$ suggested that up to ca. $50 \%$ of the total secondary organic aerosol (SOA) mass is formed through aqueous-phase reactions. Cloud droplets and atmospheric deliquescent aerosol particles may contribute to SOA formation in the atmosphere, by favoring the partitioning of soluble organic compounds that may then undergo further processes such as the direct photolysis and indirect photochemical reactions (photoinitiation, photosensitization) ${ }^{5-8}$ There is strong evidence that photosensitized chemistry may have a significant impact on SOA formation in aqueous aerosols, through photoinduced generation of high molecular weight compounds (oligomers), ${ }^{6,9}$ which could modify the physico-chemical properties of aerosols and influence global warming. ${ }^{10}$ For example, the process might decrease the cloud condensation nuclei (CCN) activity because, as demonstrated in several studies, oligomerization considerably decreases particle hygroscopicity and CCN activity of aerosols. ${ }^{11,12}$ However, the processes photosensitized by organic compounds are not currently considered in atmospheric models due to the lack of kinetic and mechanistic information. Recent studies $^{13,14}$ have suggested that pyruvic acid (PA) is a photosensitizer/photoinitiator deserving special attention in atmospheric processes. High PA concentrations have been detected in remote marine aerosols, for example, over the North Pacific. ${ }^{15}$ Long-term observations of dicarboxylic acids and related compounds in the same location revealed a significantly increasing PA trend in marine aerosols. ${ }^{16}$ Both PA and glyoxal (GL) contain the carbonyl functional group $(=\mathrm{CO})$ and they are mainly formed by photochemical degradation of dissolved organic carbon (DOC) in subsurface waters. ${ }^{17,18, \text { Kieber et al., 1990, 2016, Mopper }}$ et al., 1991, Moran and Zepp, 1997) Because of their physico-chemical properties, carbonyls are enriched at 
the sea-surface microlayer and influence the air-sea exchange of organic material. ${ }^{19}$ The microlayer GL concentrations are about one order of magnitude higher compared to the bulk: ${ }^{19}$ for instance, microlayer GL collected at an open-ocean station around $100 \mathrm{~km}$ from Bahamas was $5.9 \mathrm{nM}$, compared to $0.3 \mathrm{nM}$ in bulk water. ${ }^{18}$ The exchange with the atmosphere is an additional source of highly soluble carbonyl compounds such as GL and PA to the ocean surface. Actually, for soluble compounds such as GL and PA with respective partition coefficients $\mathrm{K}_{\mathrm{GL}}=$ $3 \times 10^{6} \mathrm{M} \mathrm{atm}^{-1}$ and $\mathrm{K}_{\mathrm{PA}}=1.7 \times 10^{5} \mathrm{M} \mathrm{atm}^{-1},{ }^{20}$ one expects the net exchange to be from the air to the ocean. GL is a particularly important carbonyl compound due to its role as SOA precursor, ${ }^{21-24}$ and its concentration in cloud droplets can range from 5 to $280 \mu \mathrm{mol} \mathrm{L}{ }^{-1}{ }^{25}$ The photolysis and the $\mathrm{OH}$-induced oxidation are considered to be the main removal processes of GL in the aqueous phase. ${ }^{26}$ The GL reactions with amines, amino acids or ammonia/ammonium ions in bulk solutions leads to formation of irreversible oligomeric species (e.g. imidazoles), indicating the potential for SOA formation (De Haan et al., 2009, De Haan et al., 2009, Powelson et al., 2014, Maxut et al., 2015, Teich et al., 2016).

Here we suggest an additional GL removal pathway carried out by irradiated PA: it is expected that this chemistry occurs at the ocean surface as well as in cloud droplets, fog and rain, where carbonyls occur at high levels. The process involving PA + GL may enhance the SOA formation rate, and yield more SOA than predicted based on $\mathrm{OH}$ oxidation chemistry. The challenges on the accurate identification of products have been tackled by means of two high-resolution mass spectrometric instruments: Orbitrap Fusion Trihybridmass Spectrometer (hereinafter, Orbitrap for short) and Ultrahigh-Resolution Electrospray Ionization Fourier Transform Ion Cyclotron Resonance Mass Spectrometer (FT-ICR-MS). Based on the broad and complex spectrum of organic products, the thermodynamic feasibility of the proposed reaction schemes was explored 
by quantum-mechanical calculations, using density functional theory (DFT) by means of the Gaussian 03 suite of programs.

\section{EXPERIMENTAL SECTION}

\section{Irradiation Procedures}

A custom-built photoreactor, made out of borosilicate glass, was used for the experiments as described in Mekic et al. 2018. ${ }^{27}$ Briefly, the photoreactor has a double-wall design with a volume of $130 \mathrm{~cm}^{3}$, and it is connected to a thermostatic bath (LAUDA ECO RE 630 GECO, Germany). Samples were magnetically stirred during irradiation, and the temperature during all the experiments was held at $293 \mathrm{~K}$.

Fresh solutions of $5 \times 10^{-3} \mathrm{~mol} \mathrm{~L}{ }^{-1} \mathrm{PA}$ (Sigma-Aldrich, 98.5\%, bidistilled using reduced pressure, $<1$ Torr) and $5 \times 10^{-3}$ mol L ${ }^{-1}$ GL (Sigma-Aldrich, 40 wt. $\%$ in $\mathrm{H}_{2} \mathrm{O}$ ) in ultrapure water (18.2 $\mathrm{M} \Omega \mathrm{cm}^{-1}$, Sartorius) were used in typical experiments. The solutions were irradiated for up to $12 \mathrm{~h}$, under equilibrium with air but without $\mathrm{O}_{2}$ addition, and at free $\mathrm{pH}$. At scheduled reaction times, $20 \mathrm{~mL}$ aliquots were withdrawn from the reactor for the needs of analysis. The UV spectra and the mass spectrometric analysis were performed immediately after sampling, thereby avoiding sample storage. All the experiments were performed in duplicate. The $\mathrm{pH}$ and the dissolved $\mathrm{O}_{2}$ concentration in the solutions containing PA+GL were $2.33 \pm 0.04$ and $8.17 \pm$ $0.05 \mathrm{mg} \mathrm{L}^{-1}$, respectively, before irradiation, and $2.81 \pm 0.03$ and $6.30 \pm 0.01 \mathrm{mg} \mathrm{L}^{-1}$, respectively, after $12 \mathrm{~h}$ of irradiation. 


\section{Photochemical Conditions}

A high pressure Xenon lamp (500 W) was used as the light source, in combination with: (1) a water filter to remove infrared radiation, and (2) a cutoff filter at wavelength $300 \mathrm{~nm} \leq \lambda \leq 700$

$\mathrm{nm}$, to provide UV-VIS radiation that is relevant to the atmospheric boundary layer. ${ }^{27}$ The lamp emission spectrum was measured with a calibrated spectroradiometer (Ocean Optics, USA) equipped with a linear-array CCD detector. The lamp was turned on one hour prior to the start of the irradiation process, to allow for stable irradiance conditions to be reached. The comparison between the photon flux emitted by the Xe-lamp and the outdoor solar actinic flux obtained with the Tropospheric Ultraviolet and Visible (TUV) model is shown in Figure S1. All the UV-visible spectra $(190 \leq \lambda \leq 700 \mathrm{~nm})$ of initial $(0 \mathrm{~h})$ and irradiated samples were recorded with a doublebeam UV-Vis spectrophotometer (Shanghai Drawell Scientific, China) in quartz cuvettes $(1 \mathrm{~cm}$ optical path length), right after sample aliquot withdrawal.

\section{Sample Analysis Using FT-ICR-MS}

Immediately after the photochemical reaction was completed, the sample aliquots were collected and diluted 1:9 (by volume) with methanol, prior to analysis with solariX XR FT-ICR-MS (Bruker Daltonik GmbH, Bremen, Germany) instrument. The selected water-to-methanol ratio is common for analysis based on previous test experiments, and methanol was verified not to react with the analytes in the samples. Methanol used in FT-ICR MS analysis was HPLC grade (Merck \& Co., Germany). We carried out control analyses and deleted the peaks that were also found in blank samples (reactant and solvent). Our solariX XR FT-ICR-MS instrument is equipped with a refrigerated, 9.4 T actively shielded superconducting magnet (Bruker Biospin, Wissembourg, France) and a Paracell analyzer cell. The samples were ionized in the negative ion detection mode using an ESI ion source (Bruker Daltonik GmbH, Bremen, Germany). The 
detection mass range was set to $m / z, 150-1000$, while ion accumulation time was set to $0.65 \mathrm{~s}$. A total of 64 continuous 4M data FT-ICR transients were co-added to enhance the signal-to-noise ratio and dynamic range. The mass spectra were calibrated externally with arginine clusters in the negative ion mode, using a linear calibration. The final spectrum was internally recalibrated with typical $\mathrm{O}_{2}$ class species peaks, using quadratic calibration in DataAnalysis 4.4 (Bruker Daltonics). A typical mass-resolving power $(\mathrm{m} / \Delta \mathrm{m} 50 \%$, in which $\Delta \mathrm{m} 50 \%$ is the magnitude of the mass spectral peak full width at half-maximum peak height) $>450,000$ was achieved at $\mathrm{m} / \mathrm{z}$ 319, with $<0.3$ ppm absolute mass error.

The custom software was used to calculate all mathematically possible formulas for all ions with a signal-to-noise ratio above 10 , using a mass tolerance of $\pm 1 \mathrm{ppm}$. For the chemical formula $\mathrm{C}_{\mathrm{c}} \mathrm{H}_{\mathrm{h}} \mathrm{O}_{\mathrm{o}} \mathrm{N}_{\mathrm{n}} \mathrm{S}_{\mathrm{s}}$, the double bond equivalent (DBE) was calculated using the following equation: $\mathrm{DBE}=(2 \mathrm{c}+2-\mathrm{h}+\mathrm{n}) / 2$ (note that the $\mathrm{O}$ and $\mathrm{S}$ atoms are neutral with respect to DBE calculation). The details of data processing are described previously. ${ }^{28,29}$

\section{Sample Analysis Using Orbitrap}

Because the FT-ICR-MS instrument is unable to detect molecular masses as low as those of both used reactants $\left(\mathrm{PA}=88.06 \mathrm{~g} \mathrm{~mol}^{-1}\right.$ and $\mathrm{GL}=58.04 \mathrm{~g} \mathrm{~mol}^{-1}$ ), it was essential to use another high-resolution analytical instrument, i.e., Orbitrap. By the use of Orbitrap it was possible to enlarge the considered mass range and obtain a complementary spectrum of information about the formed products.

Soon after the sample aliquots were withdrawn from the photoreactor, they were diluted 1:1 (by volume) with acetonitrile in order to assist with the ionization and desolvation processes. Here, we used acetonitrile HPLC grade rather than methanol because the former ensures more stable 
signals with Orbitrap (with the intensity of the total ion current maintained in $\mathrm{RSD}<5 \%$ and at least 100 mass spectra collected to get a good average). In our preliminary analysis, we used different mixing ratios of acetonitrile and laboratory samples, i.e. 1:1, 1:2 and 1:3, to analyze the effect of acetonitrile amount on MS analysis. All samples showed the same analyte species but different intensity, which was highest with a 1:1 mixing ratio.

The analytical system was operated in the negative ion detection mode with a resolution of 120,000 at $\mathrm{m} / \mathrm{z} 200$ for the Orbitrap analyzer, and a mass scan range of $\mathrm{m} / \mathrm{z} 50-750$. Before starting with the analysis of the samples, the mass analyzer was externally calibrated for mass accuracy using Thermo Scientific Pierce LTQ Velos ESI calibration solution (composed of sodium dodecyl sulfate at $\mathrm{m} / \mathrm{z}, 265$, iodine sulfonic acid sodium at $\mathrm{m} / \mathrm{z}, 514$ and Ultramark polymers at $m / z$ 1079-1979). After all the quality control processes, samples underwent directinfusion analysis with a Thermo Scientific Orbitrap Fusion Tribrid mass spectrometer equipped with quadrupole, Orbitrap, and linear ion trap mass analyzers, with a heated ESI source (Thermo Scientific, USA). The direct infusion parameters were as follows: sample flow rate $5 \mu \mathrm{L} \mathrm{min}^{-1}$; spray voltage $-3.0 \mathrm{kV}$; ion transfer tube temperature $300{ }^{\circ} \mathrm{C}$; S-lens RF $60 \%$; respective flows of sheath gas, auxiliary gas and sweep gas 5, 0 and 0 (arbitrary units), and scan mass range $\mathrm{m} / \mathrm{z} 50$ 1000.

Elemental composition assignment based on the accurate mass was performed using Xcalibur software (V3.0 Thermo Scientific) with the following constraints: ${ }^{12} \mathrm{C} \leq 50,{ }^{13} \mathrm{C} \leq 1,{ }^{1} \mathrm{H} \leq 100$, and ${ }^{16} \mathrm{O} \leq 50$. All mathematically possible elemental formulas with a mass tolerance of $\pm 5 \mathrm{ppm}$ were calculated. Mass spectral peaks with signal-to-noise ratio $>3$ were extracted from the raw files, and the peaks occurring in both sample and blank spectra were retained if their intensity in the former was 5-times larger compared to the latter. 


\section{Theoretical calculations}

The thermodynamic feasibility of the proposed reaction schemes was examined by quantummechanical calculations using density functional theory (DFT) with the Gaussian 03 suite of programs. ${ }^{30}$ The hybrid functional B3LYP ${ }^{31,32}$ was employed in conjunction with aug-cc-pVxZ $(\mathrm{x}=\mathrm{D}, \mathrm{T})$ basis sets. ${ }^{33,34}$ The solvent effects of the water medium were taken into account by the Conductor-like Polarizable Continuum Model (CPCM), using atomic radii by the United Atom Topological Model optimized for the HF/6-31G(d) level of theory (UAHF), ${ }^{35-37}$ and a dielectric constant of 78.39 for water.

The geometries of all molecules were optimized in vacuo and their vibrational frequencies were derived at the B3LYP/aug-cc-pVDZ level of theory. The refinement of the electronic energies together with the inclusion of solvation corrections by the CPCM (UAHF) methodology was performed by single-point calculations on the optimized structures at the B3LYP/aug-cc-pVTZ level of theory, henceforth denoted as B3LYP-CPCM/aug-cc-pVTZ. The harmonic oscillator and rigid rotor approximations were used for the derivation of the B3LYP/aug-cc-pVTZ electronic gas-phase thermodynamic quantities. The solution Gibbs energies were obtained by adding the calculated solvation corrections $\Delta$ Gsolv to the gas phase Gibbs energies, followed by addition of the term RT(Vmolar,gas/Vmolar,solution $)=7.93 \mathrm{~kJ} \mathrm{~mol}^{-1}$ at $298.15 \mathrm{~K}$, to convert the standard conditions from 1 atm to a solution concentration of $1 \mathrm{~mol} \mathrm{~L}^{-1}$.

The existence of possible conformers and geometric isomers for each species was also investigated, and those with the lowest B3LYP-CPCM/aug-cc-pVTZ Gibbs energies (which correspond to the prevailing molecular configurations in solution) were selected. Finally, the thermodynamic quantities of the prevailing molecular configurations were algebraically 
manipulated to yield the standard Gibbs energies $\Delta \mathrm{rGo}$ for the corresponding chemical reactions in water. The molecular geometries and the energetics of the most stable configurations for all species employed are provided in Tables S3 and S4, respectively.

The overall error in the calculated B3LYP-CPCM/aug-cc-pVTZ Gibbs energies in solution derives from two primary sources: the electronic structure calculation and the solvation model treatment. Errors in electronic structure calculations are directly reflected in deviations from the experimental values of gas-phase thermodynamic properties, such as enthalpies and Gibbs energies of formation. For a similar B3LYP/6-31+G(d) level of theory, the calculated gas-phase enthalpies of formation of 622 molecules containing $\mathrm{H}, \mathrm{C}, \mathrm{N}$ and $\mathrm{O}$ atoms were found to have a mean absolute deviation (MAD) from experiments of $11 \mathrm{~kJ} \mathrm{~mol}^{-1}$ (Tirado-Rives 2008). This is comparable to the corresponding error in the calculated gas-phase Gibbs energies. On the other hand, the aqueous solvation Gibbs energies calculated by the CPCM (UAHF) methodology using B3LYP/6-31+G(d) molecular parameters for a set of 70 organic species were found to have a MAD of $12 \mathrm{~kJ} \mathrm{~mol}^{-1}$ (Takano 2005). Therefore, the cumulative uncertainty in the calculated B3LYP-CPCM/aug-cc-pVTZ Gibbs energies in this study was estimated to be $16 \mathrm{~kJ} \mathrm{~mol}^{-1}$. 


\section{Results AND Discussion}

\section{Molecular composition by ultra-high resolution mass spectrometry}

The formation of products upon irradiation of PA and a mixture of PA/GL in the aqueous phase was assessed using electrospray ionization coupled with Orbitrap mass spectrometer. This kind of analysis is not designed to be quantitative, and in complex aqueous-phase mixtures like those evaluated in this study the different ionization efficiencies of the dissolved species can greatly influence the observed products and their peak intensities. However, relative comparisons and qualitative trends between similar samples may be derived by using this technique.

FT-ICR MS, with the ultrahigh resolution and ppb mass accuracy of its spectra, allows for a confident assignment of a unique elemental composition for each mass spectrum peak (Kew et al., 2017). It is one of the most powerful tools used for the characterization of complex organic compounds in ambient aerosols at the molecular level (Jiang et al., 2014). The analysis performed by FT-ICR-MS revealed that the molecular composition of the products formed upon 12 hours of PA irradiation was more complex than that obtained with the Orbitrap. In general, the FT-ICR-MS data showed a wider mass distribution of the reaction products compared to Orbitrap. The reasons for observing a higher number of peaks with FT-ICR-MS can be attributed to the difference in resolution and dynamic range of the two instruments. Orbitrap was set to measure ions starting from $m / z 50$, and FT-ICR-MS was tuned to measure over $m / z 150$. Thus, the two instruments complement well each other to cover a broad range of measured ion masses. Over the applied photolysis times of $6 \mathrm{~h}$ and $12 \mathrm{~h}$, most of PA and of the mixture PA+GL was transformed into product oligomers (Figure 1A and Figure 1B). Broadly speaking, the oligomeric species emerging from the photolysis of PA and of the PA+GL mixture are concentrated in the 
mass range between $\mathrm{m} / \mathrm{z}=200$ and $\mathrm{m} / \mathrm{z}=300$ (Figure 1A), and in the range between $\mathrm{m} / \mathrm{z}=50$ and $m / z=300$ (Figure 1B), respectively.

The aqueous-phase photochemistry of PA has been extensively evaluated in past studies. ${ }^{13,14,27,38-}$

42 The main photochemical products identified in those studies were pyruvic acid/acetoin $(\mathrm{m} / \mathrm{z}=$ 87), acetolactic acid $(\mathrm{m} / \mathrm{z}=131), 2$,4-dihydroxy-2-methyl-5-oxohexanoic acid $(\mathrm{DMOHA})(\mathrm{m} / \mathrm{z}=$ 175), dimethyl tartaric acid (DMTA) $(m / z=177)$, and carboxy-2,4-dihydroxy-2-methyl-5oxohexanoic acid (CDMOHA) $(m / z=219)$. Based on a previous structural identification, a mechanistic pathway has been suggested in the literature. ${ }^{14}$ DMTA (a PA dimer) and DMOHA (a PA trimer) are typically the most important oligomeric products emerging from PA photolysis. DMOHA $(m / z=175)$ and DMTA $(m / z=177)$ have been detected with the highest intensity by electro-spray ionization coupled with mass spectrometry (ESI-MS). ${ }^{41}$ 

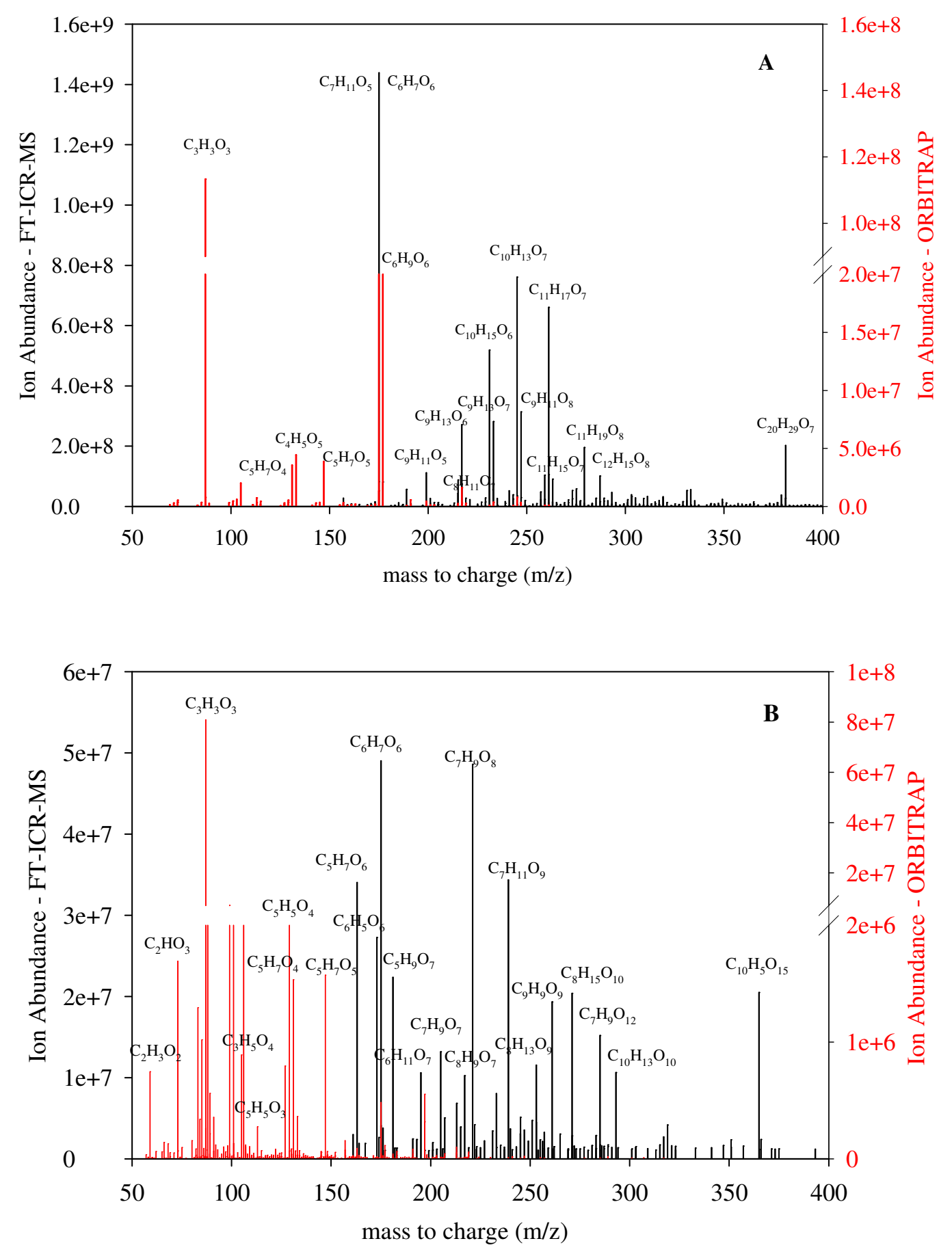

Figure 1: Comparison of relative abundances scanned in negative mode between Orbitrap (red) and FT-ICR-MS (black) A) 5mM PA after 12h irradiation; B) mixture of 5mM PA and $5 \mathrm{mM} \mathrm{GL}$ after $12 \mathrm{~h}$ irradiation. The left axis corresponds to FT-ICR-MS data and the right axis corresponds to the Orbitrap data, respectively. 
The comparison of the relative abundances of the measured ions (12 hours of PA irradiation) between Orbitrap and FT-ICR-MS is shown in Figure 1A. It is evident that Orbitrap measured ions with lower molecular mass that are well known in the literature, for example $\mathrm{C}_{6} \mathrm{H}_{7} \mathrm{O}_{6}$ (parapyruvic acid); $\mathrm{C}_{5} \mathrm{H}_{7} \mathrm{O}_{4}$ (acetolactic acid); $\mathrm{C}_{7} \mathrm{H}_{11} \mathrm{O}_{5}$ (DMOHA); $\mathrm{C}_{6} \mathrm{H}_{9} \mathrm{O}_{6}$ (dimethyltartaric acid) and $\mathrm{C}_{8} \mathrm{H}_{11} \mathrm{O}_{7}$ (CDMOHA). ${ }^{14}$ In contrast, FT-ICR-MS measured ions of higher molecular mass, up to $381 \mathrm{Da}$. There was an overlap between the ions measured by both instruments, mostly in the range between $\mathrm{m} / z 175$ and $\mathrm{m} / \mathrm{z} 250$. Compared to PA alone, the complexity of the product molecular composition markedly increased upon irradiation of the PA + GL mixture (see Figure 1B and compare with Figure 1A), suggesting the formation of PA+GL cross-products.

It has been demonstrated that the iso-abundance plots of DBE versus carbon numbers are a useful tool for the differentiation of complex organic mixtures based on the chemical composition. ${ }^{29}$ The iso-abundance plot of DBE versus carbon numbers for the detected $\mathrm{C}_{\mathrm{x}} \mathrm{H}_{\mathrm{y}} \mathrm{O}_{\mathrm{z}}$ species in this work is presented in Figure 2. DBE is the number of double bonds plus rings representing unsaturations (corresponding to a double bond) present in the organic molecule. In general, the DBE versus carbon number plots can be a helpful tool for structural interpretation by using planar limits that are defined as a straight line combining maximum detected DBE values with the corresponding carbon numbers. Specifically, these kinds of graphs are useful for predicating certain groups of compounds, because the obtained slope and intercept of the planar limits depend on the structural characteristics of the observed peaks. These plots have been widely used for the interpretation of data obtained from analysis of hydrocarbon sources, especially from petroleum, coal, crude oil and oil shale. ${ }^{43,44,45}$ The specific slope and intercept typical for the $\mathrm{C}_{\mathrm{x}} \mathrm{H}_{\mathrm{y}} \mathrm{O}_{\mathrm{z}}$ class of compounds produced by photolysis of $\mathrm{PA}+\mathrm{GL}$ is shown in Figure 2. All the data points in Figure 2 are depicted below the straight line, indicating that no 
oligomeric compounds were formed above the line in the used carbon number range. Therefore, the short-dashed line serves as a useful tool in illustrating the upper limit of the features of formed oligomers.

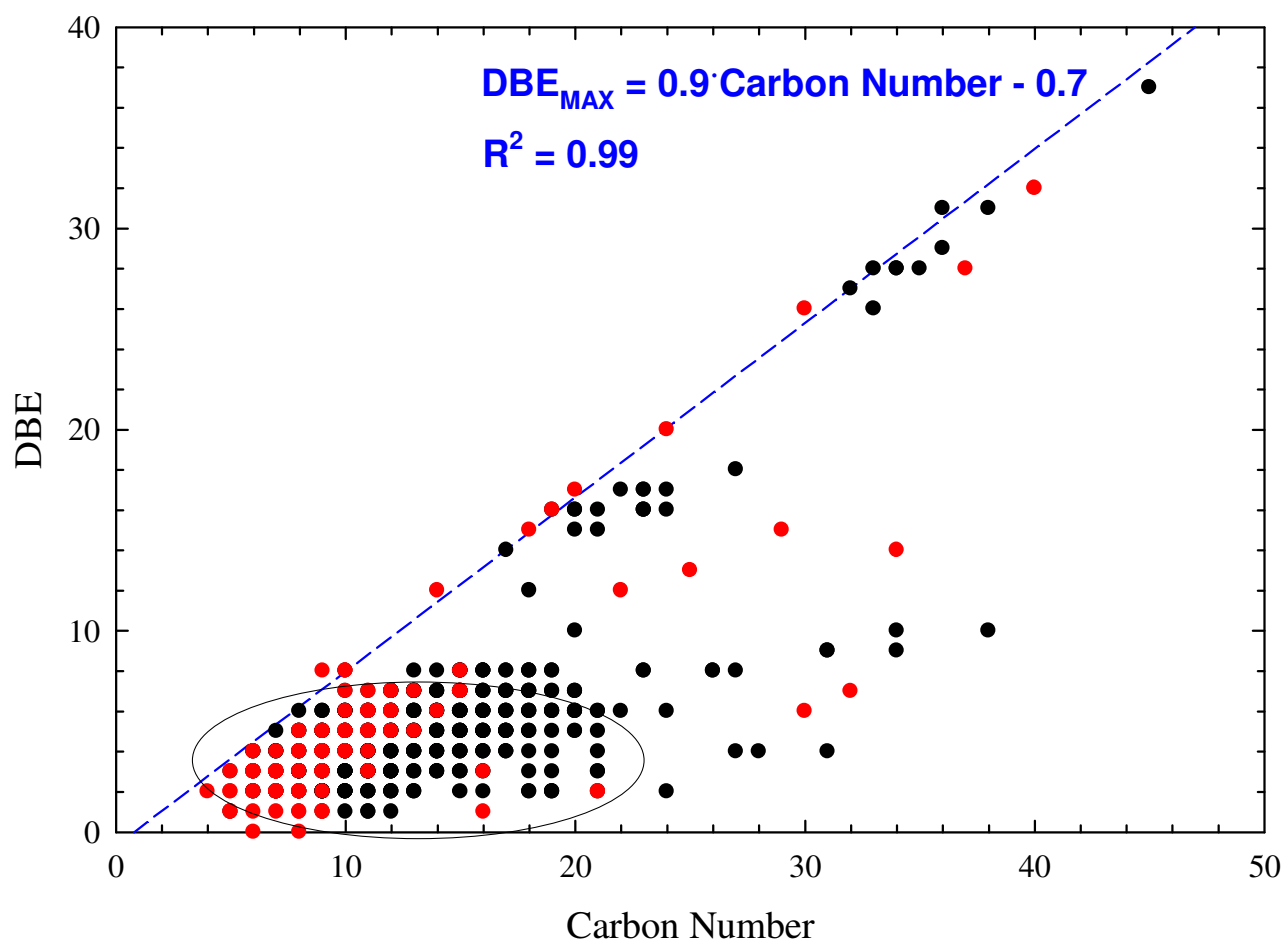

Figure 2: Iso-abundance plot of DBE versus carbon numbers for the $\mathrm{C}_{x} \mathrm{H}_{y} \mathrm{O}_{z}$ species detected upon •) 12 hours of PA irradiation, and •) 12 hours of irradiation of the mixture of PA and GL. Circled are the most abundant products. The straight short-dashed line represents the upper compositional boundary for oligomers, formed upon the reaction between PA and GL.

Figure 2 indicates that most of the $\mathrm{C}_{\mathrm{x}} \mathrm{H}_{\mathrm{y}} \mathrm{O}_{\mathrm{z}}$ products formed upon PA photodegradation exhibited DBE values in the range between 2 and 6, with 6-20 carbon atoms and 5-8 oxygen atoms (circled in Figure 2). These products should have 2-6 carbonyl groups with several oxygen-containing 
moieties like hydroxyl or carboxyl, depending on the occurrence of different oxygen atoms. They are most probably dimers or trimers of the PA initial irradiation products, thereby being higher PA oligomers. The most abundant peaks appearing after 12 hours of PA irradiation in aqueous solution are shown in Figure 1A. The instrumental mass accuracy and resolution allow for the accurate assignment of ultra-high resolution peaks above $\mathrm{m} / \mathrm{z}, 150$ to unique molecular formulas. Prominent peaks have the assigned formulas $\mathrm{C}_{7} \mathrm{H}_{11} \mathrm{O}_{7}^{-}, \mathrm{C}_{10} \mathrm{H}_{13} \mathrm{O}_{7}^{-}, \mathrm{C}_{11} \mathrm{H}_{17} \mathrm{O}_{7}^{-}$, $\mathrm{C}_{10} \mathrm{H}_{15} \mathrm{O}_{6}{ }^{-}$, and $\mathrm{C}_{9} \mathrm{H}_{11} \mathrm{O}_{8}{ }^{-}$. The oligomers formed by interaction between PA and GL under irradiation exhibit very similar features as those of PA alone, with DBE values in the range between 2 and 6 . However, on average they have fewer (5-15) carbon atoms. These oligomers should have as well 2-6 carbonyl groups with several oxygen-containing moieties like hydroxyl or carboxyl, but with different chemical formula.

The interpretation of the complex organic mass spectra generated by ultra-high resolution FTICR mass spectrometry can be simplified by plotting the $\mathrm{H} / \mathrm{C}$ against the $\mathrm{O} / \mathrm{C}$ ratio for individual assigned atomic formulas, in the form of the van Krevelen diagram (Figure 3). Figure 3 shows a two-dimensional Van Krevelen plot (H/C vs. O/C) for all compounds with $\mathrm{m} / z$ between 200 and 700. Most of the compounds emerged from photolysis of PA alone have $\mathrm{O} / \mathrm{C}$ ratios of 0.4-1.0 and $\mathrm{H} / \mathrm{C}$ ratios of $0.8-1.8$. 

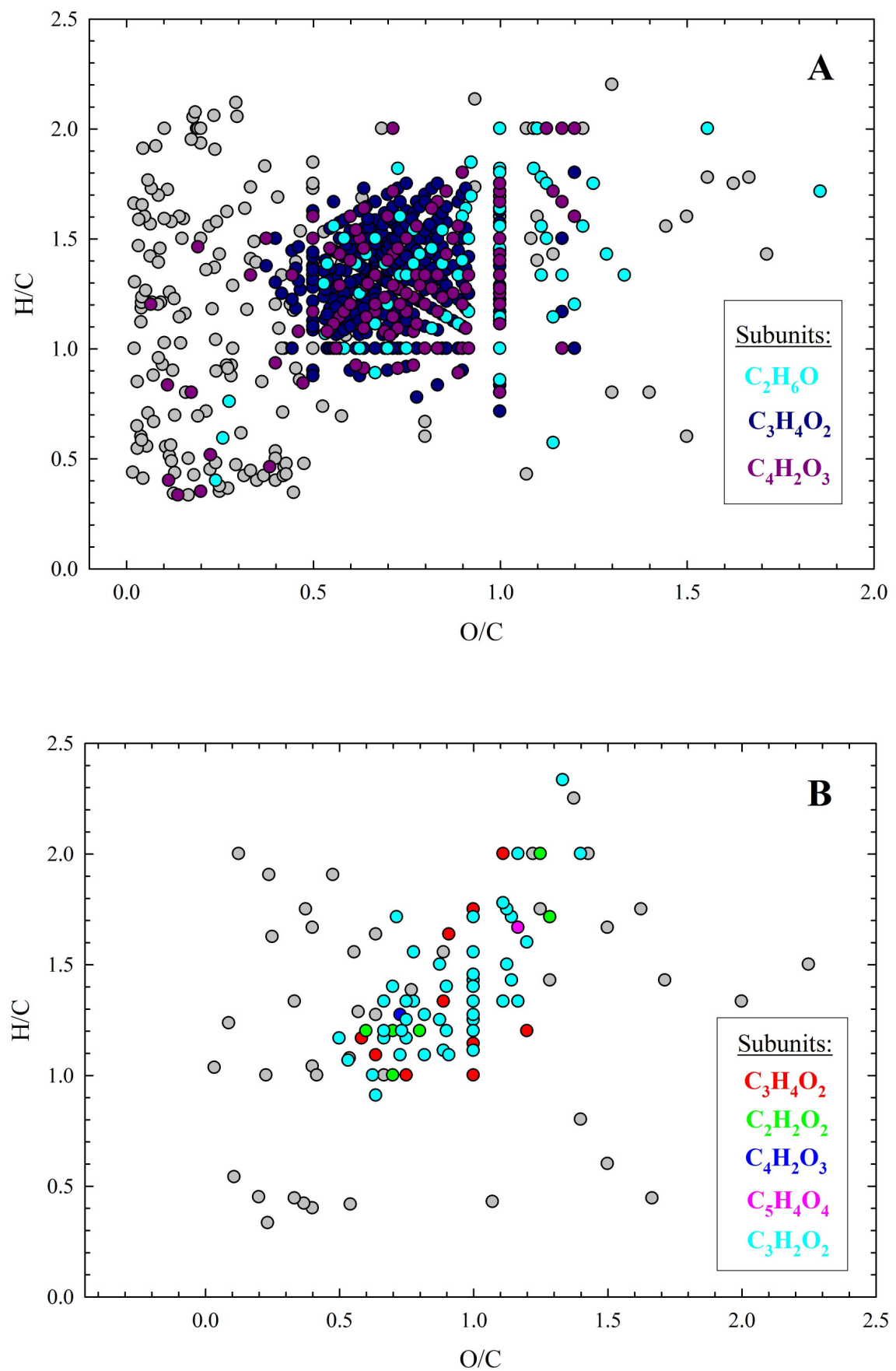

Figure 3: Van Krevelen plot of $\mathrm{C}_{x} \mathrm{H}_{y} \mathrm{O}_{z}$-compounds formed upon 12 hours of light irradiation of A) aqueous PA alone, and B) a mixture of PA and GL. The identified chemical building block increments are classified in the legends, while the rest of the molecules that do not belong to any homologous series are characterized with gray color. The FT-ICR-MS data are represented in the negative ion detection mode. 
In all the series the identified compounds produced by photolysis of PA alone are regularly separated by $\mathrm{m} / \mathrm{z}=72.021\left(\mathrm{C}_{3} \mathrm{H}_{4} \mathrm{O}_{2}\right)$. The corresponding increase in molecular weight (see Figure 1) and DBE is similar to that reported by Altieri et al., who identified 65 compounds in 9 series separated by the same mass unit $\mathrm{m} / z, 72.021$ during photoxidation experiments of $\mathrm{OH}$ radical with methylglyoxal in the aqueous phase. ${ }^{46}$ They proposed a non-radical esterification mechanism, which causes the repeated addition of $\mathrm{C}_{3} \mathrm{H}_{4} \mathrm{O}_{2}$ to the organic acid monomer and gives a series of oligoesters. ${ }^{46}$ An alternative radical pathway that could occur under irradiation might involve the photoinduced oligomerization of PA, which could be triggered by the Htransfer oxidation of ground-state PA by the PA triplet state, with a calculated $\Delta \mathrm{rGo}$ value of $54.4 \mathrm{~kJ} \mathrm{~mol}^{-1}$. While the oxidized PA species thus formed $\left(\mathrm{CH}_{3}-\mathrm{CO}-\mathrm{COO} \bullet\right)$ would undergo decarboxylation (Eugene and Guzman, 2017), the reduced radical $\left(\mathrm{CH}_{3}-\mathrm{C} \cdot(\mathrm{OH})-\mathrm{COOH}\right)$ could either give back ground-state $\mathrm{PA}\left(\mathrm{C}_{3} \mathrm{H}_{4} \mathrm{O}_{3}\right)$, or react with it as follows:

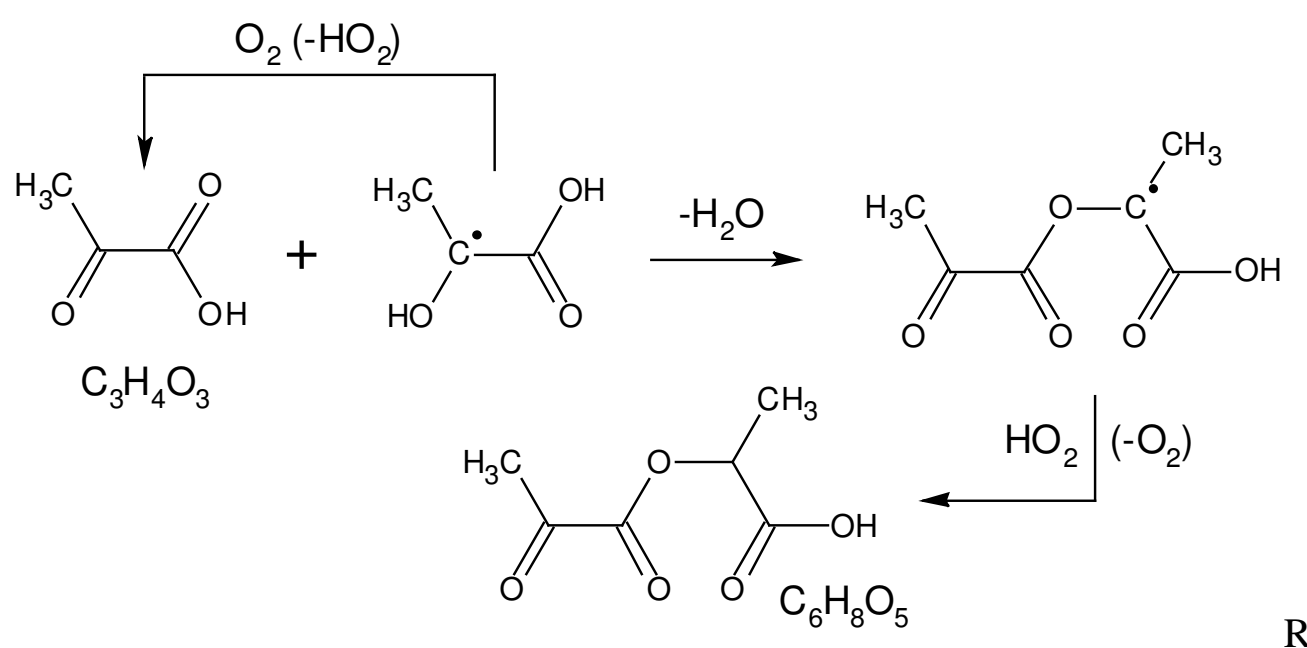


This reaction sequence was calculated to be exoergic, with an overall $\Delta \mathrm{rGo}$ value of $-62.3 \mathrm{~kJ}$ $\mathrm{mol}^{-1}$. Such a process, if reiterated by involving further $\mathrm{CH}_{3}-\mathrm{C} \cdot(\mathrm{OH})-\mathrm{COOH}$ radicals, could explain the successive additions of $\mathrm{C}_{3} \mathrm{H}_{4} \mathrm{O}_{2}$ to $\mathrm{PA}$.

We also identified covalently bonded dimers and trimers such as $\mathrm{C}_{6} \mathrm{H}_{7} \mathrm{O}_{6}$ (parapyruvic acid), $\mathrm{C}_{5} \mathrm{H}_{7} \mathrm{O}_{4}$ (acetolactic acid), $\mathrm{C}_{7} \mathrm{H}_{11} \mathrm{O}_{5}$ (DMOHA), $\mathrm{C}_{6} \mathrm{H}_{9} \mathrm{O}_{6}$ (dimethyltartaric acid) and $\mathrm{C}_{8} \mathrm{H}_{11} \mathrm{O}_{7}$ (CDMOHA) that are typically formed from the recombination of photochemically generated radical species. ${ }^{41}$ A similar pathway would also produce the oligomer $\mathrm{C}_{10} \mathrm{H}_{13} \mathrm{O}_{7}$ with $\mathrm{m} / z=$ 245.066 (Figure 1A). The formation of $\mathrm{C}_{10} \mathrm{H}_{13} \mathrm{O}_{7}$ might involve a radical derivative of a $\mathrm{PA}$ trimer, and the trimer could derive from a dimeric species produced by recombination between the excited triplet state of PA $\left({ }^{3} \mathrm{PA}^{*}\right)$ and ground-state PA [26]. During the process of ${ }^{3} \mathrm{PA}$-PA recombination, the formation of acetyl radical (Scheme 1) was also suggested as one of the key species. ${ }^{42}$ A further reaction between the trimer radical and an acetyl radical, accompanied by dehydration and decarboxylation processes might lead to the formation of $\mathrm{C}_{10} \mathrm{H}_{13} \mathrm{O}_{7}$ as shown in Scheme 1. 
Scheme 1: Proposed formation pathway of $\mathrm{C}_{10} \mathrm{H}_{13} \mathrm{O}_{7}$ based on radical recombination reactions.
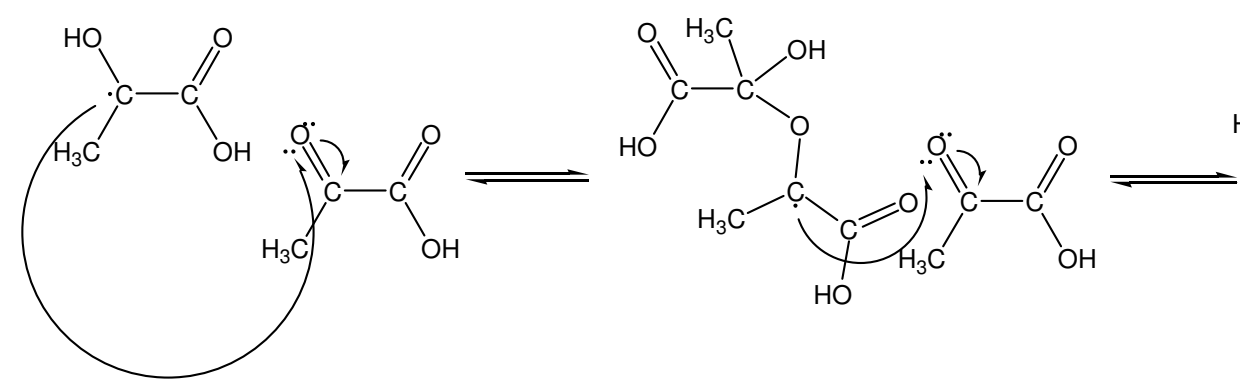<smiles>CC(OC(C)(OC(C)(O)C(=O)O)C(=O)O)C(=O)O</smiles>

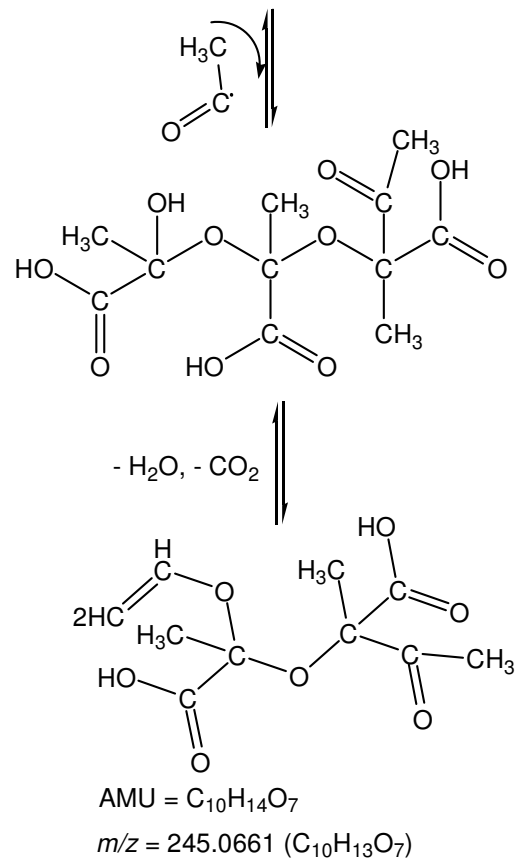

The formation of additional oligomers, always based on radical recombination reactions is described in the Supplementary Information. Another series of oligomers generated by the photolysis of PA were identified, and they differ by mass increments of $m / z, 46.041$ and 98.000 corresponding to $\mathrm{C}_{2} \mathrm{H}_{6} \mathrm{O}$ and $\mathrm{C}_{4} \mathrm{H}_{2} \mathrm{O}_{3}$, respectively (Figure $3 \mathrm{~A}$ ). The regular addition of the repeating patterns within all the series is responsible for the increase in the molecular mass of the oligomers, based on the van Krevelen plot. The molecular formula $\mathrm{C}_{2} \mathrm{H}_{6} \mathrm{O}$, which was assigned from the raw FT-ICR-MS data, appeared as a member in 56 homologous series with a convergence point at $\mathrm{O} / \mathrm{C}=0.5$ and $\mathrm{H} / \mathrm{C}=3.0$. The other extracted chemical building block increment $\left(\mathrm{C}_{4} \mathrm{H}_{2} \mathrm{O}_{3}\right)$ also appeared in 56 identified series. The converging point of the mass 
increment pattern had $\mathrm{O} / \mathrm{C}=0.75$ and $\mathrm{H} / \mathrm{C}=0.5$. The identified series of oligomers formed by adding chemical bond increments could provide crucial information about the photochemical transformations.

The oligomers formed during the photooxidation process of the PA+GL mixture are crossproducts, mainly formed upon Fischer's esterification where the nucleophilic hydroxylic group ($\mathrm{OH})$ of the glyoxalic hemiacetal ${ }^{26}$ reacts with the highly reactive carboxylic acid group (-COOH) of triplet-state PA, or with the triplet state of a PA dimer. The esterification process is accompanied by dehydration. According to this process, some chemical building block increments $\left(\mathrm{C}_{3} \mathrm{H}_{2} \mathrm{O}_{2}, \mathrm{C}_{3} \mathrm{H}_{4} \mathrm{O}_{2}, \mathrm{C}_{4} \mathrm{H}_{2} \mathrm{O}_{3}\right.$ and $\left.\mathrm{C}_{5} \mathrm{H}_{4} \mathrm{O}_{4}\right)$ were identified (Figure 3B). They are repeatedly added on the chemical chain and produce an increase of molecular mass and DBE, thereby resulting in the formation of oligomers. As an example, Scheme 2 shows the possible formation of two oligomers through the esterification process with ${ }^{3} \mathrm{PA}$, with a $\Delta_{\mathrm{r}} \mathrm{G}^{\mathrm{o}}$ value of $-231.4 \mathrm{~kJ} \mathrm{~mol}^{-1}$ at the B3LYP-CPCM/aug-cc-pVTZ level of theory. 
Scheme 2: Proposed reaction pathway of $\mathrm{m} / \mathrm{z} 239.040$ and $\mathrm{m} / \mathrm{z} 221.030$ based on Fischer's esterification
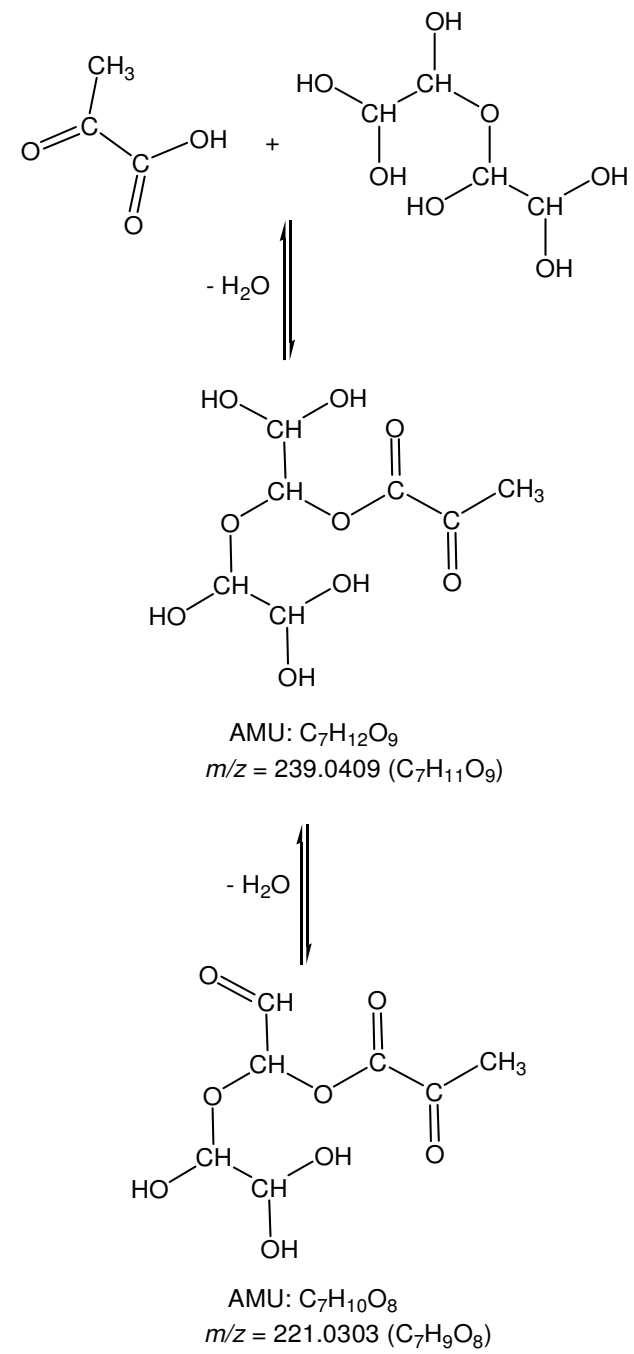

Scheme 3 shows the formation of another high molecular weight oligomer $\left(\mathrm{m} / z 261.025, \mathrm{C}_{9} \mathrm{H}_{9} \mathrm{O}_{9}\right.$, Figure 1B), involving several mass subunits $\left(\mathrm{C}_{2} \mathrm{H}_{2} \mathrm{O}_{2}, \mathrm{C}_{3} \mathrm{H}_{2} \mathrm{O}_{2}, \mathrm{C}_{4} \mathrm{H}_{2} \mathrm{O}_{3}, \mathrm{C}_{5} \mathrm{H}_{4} \mathrm{O}_{4}\right)$ that were previously identified (Figure 3). This oligomer might be formed under light irradiation of the aqueous mixture $\mathrm{PA}+\mathrm{GL}$ in a two-step radical reaction. The first step likely involves $\mathrm{CH}_{3} \mathrm{CO}$. and $\mathrm{CH}_{3} \mathrm{COCOO}$, both produced by evolution of ${ }^{3} \mathrm{PA}^{*} .{ }^{38}$ It follows a keto-enol tautomerization, the product of which reacts with the radical dimer derived from the hemiacetal (formed by 
hydrated GL + dehydrated GL) ${ }^{26}$ with final production of the oligomer with $\mathrm{m} / \mathrm{z} 261.025$ $\left(\mathrm{C}_{9} \mathrm{H}_{9} \mathrm{O}_{9}\right)$. The overall $\Delta_{\mathrm{r}} \mathrm{G}^{\mathrm{O}}$ value of the reaction sequence in Scheme 3 was calculated to be $-176.6 \mathrm{~kJ} \mathrm{~mol}^{-1}$ at the B3LYP-CPCM/aug-cc-pVTZ level of theory.

Scheme 3: The suggested radical reaction scheme leading to the formation of $\mathrm{m} / z 261.025$ $\left(\mathrm{C}_{9} \mathrm{H}_{9} \mathrm{O}_{9}\right)$

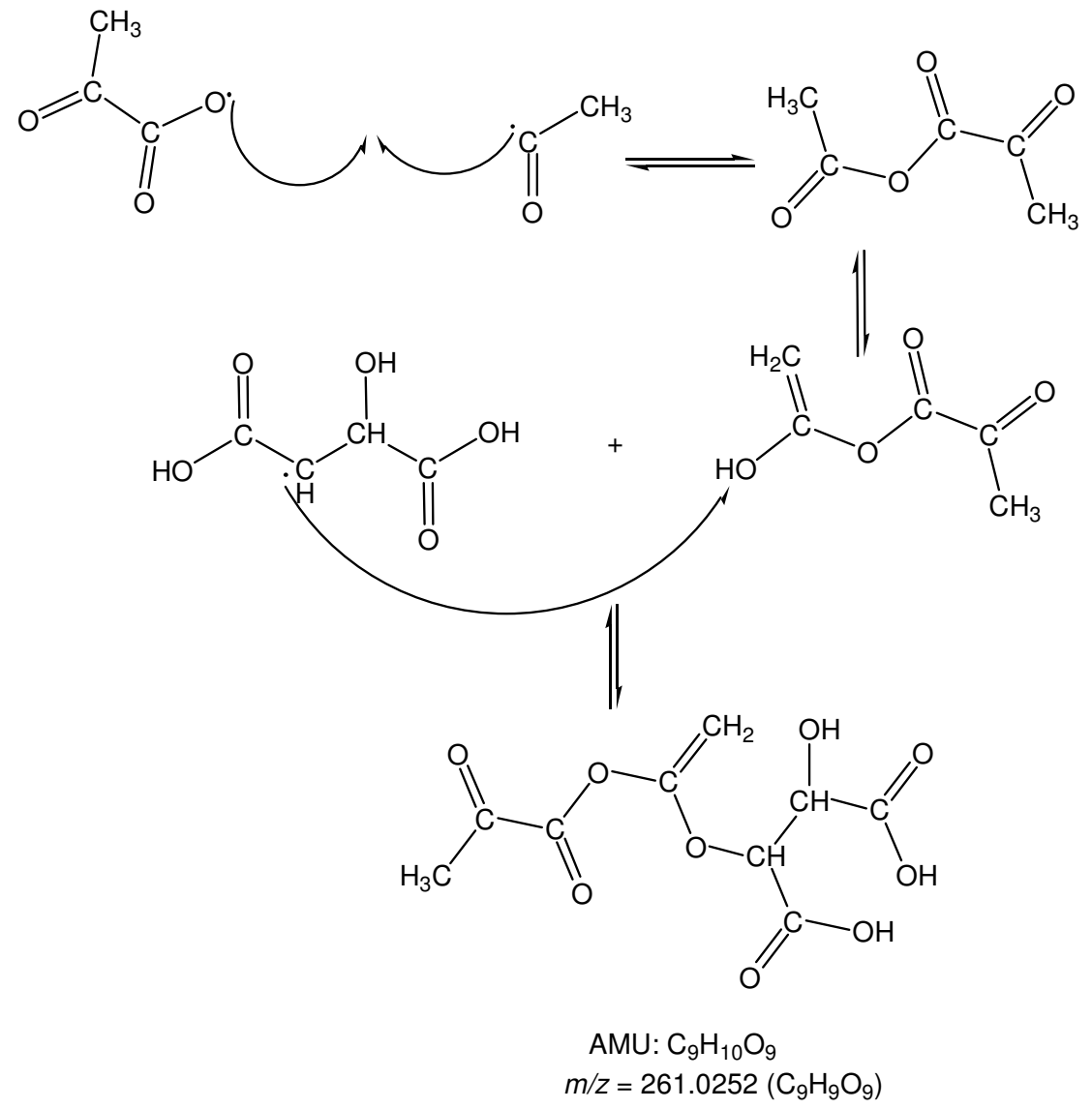

In general, reactions between ${ }^{3} \mathrm{PA} *$ and GL in aqueous solution may proceed via esterification with the hydrated forms of GL, as well as via free radical pathways including hydrogen metathesis from GL and addition to the carbonyl group of GL. Thermochemical quantities calculated for the three different types of mechanisms are presented in Table 1, using theoretical 
values of $\Delta_{\mathrm{r}} \mathrm{G}^{\mathrm{o}}$ and $\Delta_{\mathrm{r}} \mathrm{H}^{\mathrm{o}}$ calculated for typical reactions of each type. For comparison purposes, the calculated $\Delta_{\mathrm{r}} \mathrm{G}^{\mathrm{o}}$ and $\Delta_{\mathrm{r}} \mathrm{H}^{\mathrm{o}}$ values for the formation of several products upon photochemical transformation of PA alone are presented in Table 2. An inspection of the values for the esterification mechanism in Table 1 reveals that the reactions involving PA with GL as well as PA with itself are both endothermic and endoergic. However, the esterification becomes thermodynamically favored for the triplet states of $\alpha$-ketoacids, whose singlet-triplet energy splittings were calculated to be 260.4 and $246.1 \mathrm{~kJ} \mathrm{~mol}^{-1}$ for PA and its dimer $\mathrm{CH}_{3} \mathrm{C}(=\mathrm{O}) \mathrm{C}(=\mathrm{O}) \mathrm{OC}(\mathrm{OH})\left(\mathrm{CH}_{3}\right) \mathrm{COOH}$, respectively. The Gibbs energies calculated for typical reactions of each of the three mechanisms indicate that they may all occur between PA and GL in aqueous solution, in the presence of light. However, within the estimated uncertainty of $16 \mathrm{~kJ}$ $\mathrm{mol}^{-1}$, reactions occurring via the addition of ${ }^{3} \mathrm{PA} *$ to GL were calculated to be more exoergic than esterification or hydrogen-metathesis reactions, suggesting that addition may be the preferred pathway. A comparison of the $\Delta \mathrm{rGo}$ values for the possible reactions between PA and GL with those involving PA alone (shown in Table 2) suggests that the photochemical formation of cross-products between PA and GL is thermodynamically more efficient than the formation of PA transformation products. 
Table 1. Reaction Gibbs energies $\Delta_{\mathrm{r}} \mathrm{G}^{\circ}$ (in kJ mol${ }^{-1}$ ) for the three different reaction mechanisms involving PA (or PA dimer) and GL (or hydrated GL), leading to stable final products, calculated at the B3LYP-CPCM/aug-cc-pVTZ level of theory. Values in parentheses indicate the corresponding values normalized with respect to the number of PA molecules consumed in the reaction.

\begin{tabular}{|c|c|}
\hline Reaction & $\Delta_{\mathrm{r}} \mathrm{G}^{\mathbf{0}}\left(\mathrm{kJ} \mathrm{mol} \mathrm{l}^{-1}\right)$ \\
\hline $\begin{array}{l}\text { Esterification } \\
\mathrm{CH}_{3} \mathrm{C}(=\mathrm{O}) \mathrm{COOH}+\mathrm{CH}_{3} \mathrm{C}(=\mathrm{O}) \mathrm{COOH} \rightarrow \\
\mathrm{CH}_{3} \mathrm{C}(=\mathrm{O}) \mathrm{C}(=\mathrm{O}) \mathrm{OC}(\mathrm{OH})\left(\mathrm{CH}_{3}\right) \mathrm{COOH} \\
\left.\left.\left({ }^{3} \mathrm{~A}\right) \mathrm{CH}_{3} \mathrm{C}=\mathrm{O}\right) \mathrm{COOH}+\mathrm{CH}_{3} \mathrm{C}=\mathrm{O}\right) \mathrm{COOH} \rightarrow \\
\mathrm{CH}_{3} \mathrm{C}(=\mathrm{O}) \mathrm{C}(=\mathrm{O}) \mathrm{OC}(\mathrm{OH})\left(\mathrm{CH}_{3}\right) \mathrm{COOH}\end{array}$ & $\begin{array}{r}77.5 \\
-173.0\end{array}$ \\
\hline $\begin{array}{l}\mathrm{CH}_{3} \mathrm{C}(=\mathrm{O}) \mathrm{COOH}+\mathrm{HC}(\mathrm{OH})_{2} \mathrm{CHO} \rightarrow \mathrm{CH}_{3} \mathrm{C}(=\mathrm{O}) \mathrm{C}(=\mathrm{O}) \mathrm{OCH}(\mathrm{OH}) \mathrm{CHO}+ \\
\mathrm{H}_{2} \mathrm{O} \\
\mathrm{CH}_{3} \mathrm{C}(=\mathrm{O}) \mathrm{COOH}+\mathrm{HC}(\mathrm{OH})_{2} \mathrm{CH}(\mathrm{OH})_{2} \rightarrow \\
\mathrm{CH}_{3} \mathrm{C}(=\mathrm{O}) \mathrm{C}(=\mathrm{O}) \mathrm{OCH}(\mathrm{OH}) \mathrm{CH}(\mathrm{OH})_{2}+\mathrm{H}_{2} \mathrm{O} \\
\left({ }^{3} \mathrm{~A}\right) \mathrm{CH} \mathrm{CH}_{3} \mathrm{C}(=\mathrm{O}) \mathrm{COOH}+\mathrm{HC}(\mathrm{OH})_{2} \mathrm{CHO} \rightarrow \\
\mathrm{CH}_{3} \mathrm{C}(=\mathrm{O}) \mathrm{C}(=\mathrm{O}) \mathrm{OCH}(\mathrm{OH}) \mathrm{CHO}+\mathrm{H}_{2} \mathrm{O} \\
\left({ }^{3} \mathrm{~A}\right) \mathrm{CH} \mathrm{CH}_{3} \mathrm{C}(=\mathrm{O}) \mathrm{COOH}+\mathrm{HC}(\mathrm{OH})_{2} \mathrm{CH}(\mathrm{OH})_{2} \rightarrow \\
\mathrm{CH}_{3} \mathrm{C}(=\mathrm{O}) \mathrm{C}(=\mathrm{O}) \mathrm{OCH}(\mathrm{OH}) \mathrm{CH}(\mathrm{OH})_{2}+\mathrm{H}_{2} \mathrm{O}\end{array}$ & $\begin{array}{r}21.0 \\
33.8 \\
-229.6 \\
-216.7\end{array}$ \\
\hline $\begin{array}{l}\mathrm{CH}_{3} \mathrm{C}(=\mathrm{O}) \mathrm{C}(=\mathrm{O}) \mathrm{OC}(\mathrm{OH})\left(\mathrm{CH}_{3}\right) \mathrm{COOH}+\mathrm{HC}(\mathrm{OH})_{2} \mathrm{CHO} \rightarrow \\
\mathrm{CH}_{3} \mathrm{C}(=\mathrm{O}) \mathrm{C}(=\mathrm{O}) \mathrm{OC}(\mathrm{OH})\left(\mathrm{CH}_{3}\right) \mathrm{C}(=\mathrm{O}) \mathrm{OCH}(\mathrm{OH}) \mathrm{CHO}+\mathrm{H}_{2} \mathrm{O} \\
\mathrm{CH}_{3} \mathrm{C}(=\mathrm{O}) \mathrm{C}(=\mathrm{O}) \mathrm{OC}(\mathrm{OH})\left(\mathrm{CH}_{3}\right) \mathrm{COOH}+\mathrm{HC}(\mathrm{OH})_{2} \mathrm{CH}(\mathrm{OH})_{2} \rightarrow \\
\mathrm{CH}_{3} \mathrm{C}(=\mathrm{O}) \mathrm{C}(=\mathrm{O}) \mathrm{OC}(\mathrm{OH})\left(\mathrm{CH}_{3}\right) \mathrm{C}(=\mathrm{O}) \mathrm{OCH}(\mathrm{OH}) \mathrm{CH}(\mathrm{OH})_{2}+\mathrm{H}_{2} \mathrm{O} \\
\left({ }^{3} \mathrm{~A}\right) \mathrm{CH} \mathrm{CH}_{3} \mathrm{C}(=\mathrm{O}) \mathrm{C}(=\mathrm{O}) \mathrm{OC}(\mathrm{OH})\left(\mathrm{CH}_{3}\right) \mathrm{COOH}+\mathrm{HC}(\mathrm{OH})_{2} \mathrm{CHO} \rightarrow \\
\mathrm{CH}_{3} \mathrm{C}(=\mathrm{O}) \mathrm{C}(=\mathrm{O}) \mathrm{OC}(\mathrm{OH})\left(\mathrm{CH}_{3}\right) \mathrm{C}(=\mathrm{O}) \mathrm{OCH}(\mathrm{OH}) \mathrm{CHO}+\mathrm{H}_{2} \mathrm{O} \\
\left({ }^{3} \mathrm{~A}\right) \mathrm{CH} \mathrm{CH}_{3} \mathrm{C}(=\mathrm{O}) \mathrm{C}(=\mathrm{O}) \mathrm{OC}(\mathrm{OH})\left(\mathrm{CH} \mathrm{CH}_{3}\right) \mathrm{COOH}+\mathrm{HC}(\mathrm{OH})_{2} \mathrm{CH}(\mathrm{OH})_{2} \rightarrow \\
\mathrm{CH}_{3} \mathrm{C}(=\mathrm{O}) \mathrm{C}(=\mathrm{O}) \mathrm{OC}(\mathrm{OH})\left(\mathrm{CH}_{3}\right) \mathrm{C}(=\mathrm{O}) \mathrm{OCH}(\mathrm{OH}) \mathrm{CH}(\mathrm{OH})_{2}+\mathrm{H}_{2} \mathrm{O}\end{array}$ & $\begin{array}{r}30.4 \\
37.0 \\
-209.0 \\
-202.4\end{array}$ \\
\hline $\begin{array}{l}\text { Pyruvate-Glyoxal H-Metathesis } \\
\left({ }^{3} \mathrm{~A}\right) \mathrm{CH}_{3} \mathrm{C}(=\mathrm{O}) \mathrm{COOH}+\mathrm{HC}(=\mathrm{O}) \mathrm{CHO} \rightarrow \mathrm{HOOCC}(\mathrm{OH})\left(\mathrm{CH}_{3}\right) \mathrm{C}(=\mathrm{O}) \mathrm{CHO} \\
3\left({ }^{3} \mathrm{~A}\right) \mathrm{CH}_{3} \mathrm{C}(=\mathrm{O}) \mathrm{COOH}+\mathrm{CH}_{3} \mathrm{C}(=\mathrm{O}) \mathrm{COOH}+2 \mathrm{HC}(=\mathrm{O}) \mathrm{CHO} \rightarrow \\
\mathrm{HOOCC}(\mathrm{OH})\left(\mathrm{CH}_{3}\right) \mathrm{C}(\mathrm{OH})\left(\mathrm{CH}_{3}\right) \mathrm{COOH}+\mathrm{HOOCC}(\mathrm{OH})\left(\mathrm{CH}_{3}\right) \mathrm{C}(=\mathrm{O}) \mathrm{CHO} \\
+\mathrm{HOOCC}(=\mathrm{O}) \mathrm{CH}_{2} \mathrm{C}(=\mathrm{O}) \mathrm{CHO}^{-} \\
3\left({ }^{3} \mathrm{~A}\right) \mathrm{CH}_{3} \mathrm{C}(=\mathrm{O}) \mathrm{COOH}+\mathrm{CH}_{3} \mathrm{C}(=\mathrm{O}) \mathrm{COOH}+2 \mathrm{HC}(=\mathrm{O}) \mathrm{CHO} \rightarrow \\
\mathrm{HOOCC}(\mathrm{OH})\left(\mathrm{CH}_{3}\right) \mathrm{C}(\mathrm{OH})\left(\mathrm{CH}_{3}\right) \mathrm{COOH}+\mathrm{HOOCC}(\mathrm{OH})\left(\mathrm{CH}_{3}\right) \mathrm{C}(=\mathrm{O}) \mathrm{CHO} \\
+\mathrm{CH}_{3} \mathrm{C}(=\mathrm{O}) \mathrm{C}(=\mathrm{O}) \mathrm{OC}(=\mathrm{O}) \mathrm{CHO} \\
\left.2\left({ }^{3} \mathrm{~A}\right) \mathrm{CH} \mathrm{CH}_{3} \mathrm{C}=\mathrm{O}\right) \mathrm{COOH}+2 \mathrm{HC}(=\mathrm{O}) \mathrm{CHO} \rightarrow \\
\mathrm{HOOCC}(\mathrm{OH})\left(\mathrm{CH}_{3}\right) \mathrm{C}(\mathrm{OH})\left(\mathrm{CH}_{3}\right) \mathrm{COOH}+\mathrm{HC}(=\mathrm{O}) \mathrm{C}(=\mathrm{O}) \mathrm{C}(=\mathrm{O}) \mathrm{CHO}\end{array}$ & $\begin{array}{l}-229.7 \\
-664.9 \\
(-166.2) \\
-639.8 \\
(-160.0) \\
-426.9 \\
(-213.5)\end{array}$ \\
\hline
\end{tabular}




\begin{tabular}{lc}
\hline Pyruvate-Glyoxal Addition & \\
$\left.{ }^{3} \mathrm{~A}\right) \mathrm{CH}_{3} \mathrm{C}(=\mathrm{O}) \mathrm{COOH}+\mathrm{HC}(=\mathrm{O}) \mathrm{CHO} \rightarrow$ & -291.5 \\
cyclo- $\mathrm{CH}_{3} \mathrm{C}(-)(\mathrm{COOH}) \mathrm{OC}(=\mathrm{O}) \mathrm{CH}_{2} \mathrm{O}(-)$ & -10.1 \\
$\left({ }^{3} \mathrm{~A}\right) \mathrm{CH}_{3} \mathrm{C}(=\mathrm{O}) \mathrm{COOH}+\mathrm{HC}(=\mathrm{O}) \mathrm{CHO} \rightarrow$ & \\
cyclo- $\mathrm{CH}_{3} \mathrm{C}(\mathrm{O}-)(\mathrm{COOH}) \mathrm{C}(=\mathrm{O}) \mathrm{CH}_{2} \mathrm{O}(-)$ & -244.9 \\
$\left.{ }^{3} \mathrm{~A}\right) \mathrm{CH}_{3} \mathrm{C}(=\mathrm{O}) \mathrm{COOH}+\mathrm{HC}(=\mathrm{O}) \mathrm{CHO} \rightarrow \mathrm{CH}_{2}=\mathrm{C}(\mathrm{COOH}) \mathrm{OC}(=\mathrm{O}) \mathrm{CH}_{2} \mathrm{OH}$ & -164.2 \\
$\left.{ }^{3} \mathrm{~A}\right) \mathrm{CH}_{3} \mathrm{C}(=\mathrm{O}) \mathrm{COOH}+\mathrm{HC}(=\mathrm{O}) \mathrm{CHO} \rightarrow$ cyclo-$-\mathrm{C}(-) \mathrm{H}_{2} \mathrm{C}(\mathrm{O}-)$ & \\
$(\mathrm{COOH}) \mathrm{C}(=\mathrm{O}) \mathrm{CH}_{2} \mathrm{OH}$ & \\
\hline
\end{tabular}

Table 2. Reaction Gibbs energies $\Delta_{\mathrm{r}} \mathrm{G}^{\circ}$ (in $\mathrm{kJ} \mathrm{mol}^{-1}$ ) for the formation of major final products from the photochemical transformation of PA, calculated at the B3LYP-CPCM/aug-cc-pVTZ level of theory. Values in parentheses indicate the corresponding values normalized with respect to the number of PA molecules consumed in the reaction.

\begin{tabular}{|c|c|}
\hline Reaction & $\Delta_{\mathrm{r}} \mathrm{G}^{0}\left(\mathrm{~kJ} \mathrm{~mol}^{-1}\right)$ \\
\hline $\begin{array}{l}\text { Acetoin production } \\
\left({ }^{3} \mathrm{~A}\right) \mathrm{CH}_{3} \mathrm{C}(=\mathrm{O}) \mathrm{COOH}+\mathrm{CH}_{3} \mathrm{C}(=\mathrm{O}) \mathrm{COOH} \rightarrow \mathrm{CH}_{3} \mathrm{C}(=\mathrm{O}) \mathrm{CH}(\mathrm{OH}) \mathrm{CH}_{3} \\
+2 \mathrm{CO}_{2}\end{array}$ & $\begin{array}{c}-380.6 \\
(-190.3)\end{array}$ \\
\hline $\begin{array}{l}\text { Acetolactic acid production } \\
\left({ }^{3} \mathrm{~A}\right) \mathrm{CH}_{3} \mathrm{C}(=\mathrm{O}) \mathrm{COOH}+\mathrm{CH}_{3} \mathrm{C}(=\mathrm{O}) \mathrm{COOH} \rightarrow \\
\mathrm{HOOCC}(\mathrm{OH})\left(\mathrm{CH}_{3}\right) \mathrm{C}(=\mathrm{O}) \mathrm{CH}_{3}+\mathrm{CO}_{2}\end{array}$ & $\begin{array}{c}-301.5 \\
(-150.8)\end{array}$ \\
\hline $\begin{array}{l}\text { Parapyruvic acid production } \\
\left({ }^{3} \mathrm{~A}\right) \mathrm{CH}_{3} \mathrm{C}(=\mathrm{O}) \mathrm{COOH}^{2} \mathrm{CH}_{3} \mathrm{C}(=\mathrm{O}) \mathrm{COOH} \rightarrow \\
\mathrm{HOOCC}(\mathrm{OH})\left(\mathrm{CH}_{3}\right) \mathrm{CH}_{2} \mathrm{C}(=\mathrm{O}) \mathrm{COOH}\end{array}$ & $\begin{array}{c}-199.6 \\
(-99.8)\end{array}$ \\
\hline $\begin{array}{l}\text { DMOHA production } \\
2\left({ }^{3} \mathrm{~A}\right) \mathrm{CH}_{3} \mathrm{C}(=\mathrm{O}) \mathrm{COOH}+\mathrm{CH}_{3} \mathrm{C}(=\mathrm{O}) \mathrm{COOH} \rightarrow \\
\mathrm{HOOCC}(\mathrm{OH})\left(\mathrm{CH}_{3}\right) \mathrm{CH}_{2} \mathrm{CH}(\mathrm{OH}) \mathrm{C}(=\mathrm{O}) \mathrm{CH}_{3}+2 \mathrm{CO}_{2}\end{array}$ & $\begin{array}{c}-597.5 \\
(-199.2)\end{array}$ \\
\hline $\begin{array}{l}\text { DMTA production } \\
2\left({ }^{3} \mathrm{~A}\right) \mathrm{CH}_{3} \mathrm{C}(=\mathrm{O}) \mathrm{COOH}+2 \mathrm{CH}_{3} \mathrm{C}(=\mathrm{O}) \mathrm{COOH} \rightarrow \\
\mathrm{HOOCC}(\mathrm{OH})\left(\mathrm{CH}_{3}\right) \mathrm{C}(\mathrm{OH})\left(\mathrm{CH}_{3}\right) \mathrm{COOH}+ \\
\mathrm{HOOCC}(=\mathrm{O}) \mathrm{CH}_{2} \mathrm{CH}_{2} \mathrm{C}(=\mathrm{O}) \mathrm{COOH}\end{array}$ & $\begin{array}{c}-396.0 \\
(-99.0)\end{array}$ \\
\hline $\begin{array}{l}\text { CDMOHA production } \\
2\left({ }^{3} \mathrm{~A}\right) \mathrm{CH}_{3} \mathrm{C}(=\mathrm{O}) \mathrm{COOH}+\mathrm{CH}_{3} \mathrm{C}(=\mathrm{O}) \mathrm{COOH} \rightarrow \\
\mathrm{HOOCC}(\mathrm{OH})\left(\mathrm{CH}_{3}\right) \mathrm{CH}_{2} \mathrm{C}(\mathrm{OH})(\mathrm{COOH}) \mathrm{C}(=\mathrm{O}) \mathrm{CH}_{3}+\mathrm{CO}_{2}\end{array}$ & $\begin{array}{c}-491.3 \\
(-163.8)\end{array}$ \\
\hline
\end{tabular}




\section{CONCLUSION}

It has been suggested that in the clouds and the aerosol deliquescent particles the cross-reactions of organic compounds would be more likely than the self-reactions. ${ }^{47}$ Here we suggest that even at low GL concentration in a cloud droplet, PA may form oligomers with GL and effectively prevent GL evaporation, which would otherwise take place if the acetal pathway alone were operational. The acetal pathway does in fact produce oligomeric species reversibly, which then yield back monomeric and more volatile GL.

A comprehensive understanding of the relative importance of the reaction pathways leading to irreversible formation of higher-molecular-weight oxidation products (oligomers) is of paramount importance to accurately model the atmospheric photochemical processes of organic compounds. ${ }^{48}$

The experiments described in this paper provide new data and insights into the photochemical mechanisms by which PA and GL may be processed in the cloud water, thereby causing photochemical cycling of multifunctional compounds. This study suggests that product complexity and oligomer formation become increasingly important when two key atmospheric species such as PA and GL are found together, which is usually the case in the cloud water, in aerosol deliquescent particles and in the sea surface water. Hence, photosensitized reactions

involving GL can play an important role in SOA formation. ${ }^{49,50}$ Much more experimental work and theoretical calculations are needed for a better understanding of the light-induced reactions and their importance for atmospheric processes, especially in comparison to $\mathrm{OH}$ radical reactions in the cloud droplets and aerosols. 


\section{Acknowledgements}

DV acknowledges financial support by MIUR-PNRA (project PNRA14_00026). YGL acknowledges the computational support by the European Grid Infrastructure (EGI) through the National Grid Infrastructures NGI_GRNET, HellasGRID as part of the SEE Virtual Organisation. YGL acknowledges support of this work by the project MIS 5002567, implemented under the "Action for the Strategic Development on the Research and Technological Sector", funded by the Operational Programme "Competitiveness, Entrepreneurship and Innovation" (NSRF 2014-2020) and co-financed by Greece and the European Union (European Regional Development Fund). 


\section{References}

A. Maxut, B. Nozière, B. Fenet and H. Mechakra, Formation mechanisms and yields of small imidazoles from reactions of glyoxal with $\mathrm{NH} 4+$ in water at neutral $\mathrm{pH}$, Phys. Chem. Chem. Phys., 2015,17, 20416-20424.

De Haan, D. O.; Corrigan, A. L.; Smith, K. W.; Stroik, D. R.; Turley, J. J.; Lee, F. E.; Tolbert, M. A.; Jimenez, J. L.; Cordova, K. E.; Ferrell, G. R. Secondary organic aerosol-forming reactions of glyoxal with amino acids. Environ. Sci. Technol. 2009, 43 (8), 2818-2824.

De Haan, D. O.; Tolbert, M. A.; Jimenez, J. L. Atmospheric condensed-phase reactions of glyoxal with methylamine. Geophys. Res. Lett. 2009, 36 (L11), L11819.

Kieber, D. J., W. C. Keene, A. A. Frossard, M. S. Long, J. R. Maben, L. M. Russell, J. D. Kinsey, I. M. B. Tyssebotn, P. K. Quinn, and T. S. Bates (2016), Coupled ocean-atmosphere loss of marine refractory dissolved organic carbon, Geophys. Res. Lett., 43, 2765-2772, doi:10.1002/2016GL068273.

Kieber, R. J., X. Zhou, and K. Mopper (1990), Formation of carbonyl compounds from UVinduced photodegradation of humic substances in natural waters: Fate of riverine carbon in the sea, Limnol. Oceanogr., 35(7), 1503-1515, doi:10.4319/lo.1990.35.7.1503.

Monique Teich, Dominik van Pinxteren, Simonas Kecorius, Zhibin Wang, and Hartmut Herrmann, First quantification of imidazoles in ambient aerosol particles: Potential

Mopper, K., X. Zhou, R. J. Kieber, D. J. Kieber, R. J. Sikorski, and R. D. Jones (1991), Photochemical degradation of dissolved organic carbon and its impact on the oceanic carbon cycle, Nature, 353(6339), 60-62, doi:10.1038/353060a0.

Moran, M. A., and R. G. Zepp (1997), Role of photoreactions in the formation of biologically labile compounds from dissolved organic matter, Limnol. Ocermogr., 42(6), 1307-1316.

photosensitizers, brown carbon constituents and hazardous components, Environ. Sci. Technol., 2016, 50 (3), pp 1166-1173

Powelson, M. H.; Espelien, B. M.; Hawkins, L. N.; Galloway, M. M.; De Haan, D. O. Brown carbon formation by aqueous-phase carbonyl compound reactions with amines and ammonium sulfate. Environ. Sci. Technol. 2014, 48 (2), 985-993.

Takano, Y.; Houk, K. N. Benchmarking the Conductor-like Polarizable Continuum Model (CPCM) for Aqueous Solvation Free Energies of Neutral and Ionic Organic Molecules. J. Chem. Theory Comput. 2005, 1, 70-77.

Tirado-Rives, J.; Jorgensen, W. L. Performance of B3LYP Density Functional Methods for a Large Set of Organic Molecules. J. Chem. Theory Comput. 2008, 4, 297-306.

William Kew, W.; Blackburn, J. W. T.; Clarke, D. J.; Uhrin, D. Rapid Commun. Mass Spectrom. 2017, 31, 658-662.

(1) Herrmann, H. Kinetics of Aqueous Phase Reactions Relevant for Atmospheric Chemistry. Chem. Rev. 2003, 103, 4691-4716. 
(2) Herrmann, H.; Schaefer, T.; Tilgner, A.; Styler, A. S.; Weller, C.; Teich, M.; Otto, T. Tropospheric aqueous-phase chemistry: kinetics, mechanisms, and its coupling to a changing gas phase. Chem. Rev. 2015, 115, 4259-4334.

(3) Gligorovski, S.; Strekowski, R.; Barbati, S.; Vione, D. Environmental Implications of Hydroxyl Radicals ((•)OH). Chem. Rev. 2015, 115 (24), 13051-13092.

(4) Ervens, B.; Turpin, B. J.; Weber, R. J. Secondary organic aerosol formation in cloud droplets and aqueous particles (aqSOA): a review of laboratory, field and model studies. Atmos. Chem. Phys. 2011, 11, 11069-11102.

(5) Gómez Alvarez, E.; Wortham, H.; Strekowski, R.; Zetzsch, C.; Gligorovski, S. Atmospheric photosensitized heterogeneous and multiphase reactions: from outdoors to indoors. Environ. Sci. Technol. 2012, 46, 1955-1963.

(6) Renard, P.; Reed Harris, A. E.; Rapf, R. J.; Ravier, S.; Demelas, C.; Coulomb, B.; Quivet, E.; Vaida, V.; Monod, A. Aqueous Phase Oligomerization of Methyl Vinyl Ketone by Atmospheric Radical Reactions. J. Phys. Chem. C. 2014, 118, 29421-29430.

(7) Rapf, R. J.; Perkins, R. J.; Dooley, M. R.; Kroll, J. A.; Carpenter, B. K.; Vaida, V. Environmental Processing of Lipids Driven by Aqueous Photochemistry of $\alpha$-Keto Acids. ACS Cent. Sci. 2018, 4 (5), 624-630.

(8) McNeill, V. F. Aqueous Organic Chemistry in the Atmosphere: Sources and Chemical Processing of Organic Aerosols. Environ. Sci. Technol. 2015, 49, 1237-1244.

(9) De Laurentiis, E. ; Socorro, J. ; Vione, D. ; Quivet, E. ; Brigante, M. ; Mailhot, G. ; Wortham, H. ; Gligorovski, S. Phototransformation of 4-phenoxyphenol sensitized by 4carboxybenzophenone: Evidence of new photochemical pathways in the bulk aqueous phase and on the surface of aerosol deliquescent particles. Atmos. Environ. 2013, 81, 569-578.

(10) Xu, W.; Guo, S.; Gomez-Hernandez, M.; Zamora, M. L.; Secrest, J.; Marrero-Ortiz, W.; Zhang, A. L.; Collins, D. R.; Zhang, R. Cloud forming potential of oligomers relevant to secondary organic aerosols. Geophys. Res. Lett., 2014, 41, 6538-6545.

(11) VanReken, T. M.; Ng, N. L.; Flagan, R. C.; Seinfeld, J. H. J. Geophys. Res. 2005, 110, 19.

(12) Petters, M. D.; Kreidenweis, S. M.; Snider, J. R.; Koehler, K. A.; Wang, Q.; Prenni, A. J.; Xu, W.; Guo, S.; Gomez-Hernandez, M.; Zamora, M. L.; Secrest, J.; Marrero-Ortiz, W.; Zhang, A. L.; Collins, D. R.; Zhang, R. Geophys. Res. Lett. 2014, 41, 6538-6545.

(13) Grgic, I.; Nieto-Gligorovski, L. I.; Net, S.; Temime-Roussel, B.; Gligorovski, S.; Wortham, H. Light induced multiphase chemistry of gas-phase ozone on aqueous pyruvic and oxalic acids. Phys. Chem. Chem. Phys. 2010, 12, 698-707.

(14) Rapf, R. J.; Perkins, R. J.; Carpenter, B. K.; Vaida, V. Mechanistic description of photochemical oligomer formation from aqueous pyruvic acid. J. Phys. Chem. A. 2017, 121, 4272-4282.

(15) Kawamura, K.; Sakaguchi, F. Molecular distributions of water soluble dicarboxylic acids in marine aerosols over the Pacific Ocean including tropics. J. Geophys. Res. Atmos. 1999, 104, 3501-3509. 
(16) Boreddy, S. K. R.; Kawamura, K.; Tachibana, E. Long term (2001-2013) obervations of water-soluble dicarboxylic acids and related compounds over the western North Pacific: trends, seasonality and source appointment. Sci. Rep. 2017, 7, 1-12.

(17) Kieber, D. J.; Mopper, K. Photochemical formation of glyoxalic and pyruvic acids in seawaters. Mar. Chem. 1987, 21, 135-149.

(18) Zhou, X.; Mapper, K. Photochemical production of low-molecular-weight carbonyl compounds in seawater and surface microlayer and their air-sea exchange. Mar. Chem. 1997, 56, 201-213.

(19) Carpenter, J. L.; Nightingale, P. D. Chemistry and Release of Gases from the Surface Ocean. Chem. Rev. 2015, 115 (10), 4015-4034.

(20) Khan, I.; Brimblecombe, P.; Clegg, S. L. Solubilities of pyruvic acid and the lower $\left(\mathrm{C}_{1^{-}}\right.$ $\mathrm{C}_{6}$ ) carboxylic acids. Experimental determination of equilibrium vapour pressures above pure aqueous and salt solutions. J. Atmos. Chem. 1995, 22, 285-302.

(21) Altieri, K.; Carlton, A. G.; Lim, H.-J.; Turpin, B. J.; Seitzinger, S. P. Evidence for oligomer formation in clouds: Reaction of isoprene oxidation products. Environ. Sci. Technol. 2006, 40, 4956-4960.

(22) Carlton, A. G.; Turpin, B. J.; Altieri, K. E.; Seitzinger, S.; Reff, A.; Lim, H-J.; Ervens, B. Oxalic acid and SOA production from glyoxal: Results of aqueous phase photooxidation experiments. Atmos. Environ. 2007, 41, 7588-7602.

(23) Tan, Y.; Perri, M. J.; Seitzinger, S. P.; Turpin, B. J. Effects of Precursor Concentration and Acidic Sulfate in Aqueous Glyoxal-OH Radical Oxidation and Implications for Secondary Organic Aerosol. Environ. Sci. Technol. 2009, 43, 8105-8112.

(24) Ervens, B.; Volkamer, R. Glyoxal processing by aerosol multiphase chemistry: towards a kinetic modeling framework of secondary organic aerosol formation in aqueous particles. Atmos. Chem. Phys. 2010, 10, 8219-8244.

(25) Munger, J.W.; Collett, J.; Daube Jr., B.C.; Hoffmann, M.R. Fogwater chemistry at Riverside, California. Atmos. Environ. 1990, 24, 185-205.

(26) Lim, Y. B.; Tan, Y.; Perri, M. J.; Seitzinger, S. P.; Turpin, B. J. Aqueous chemistry and its role in secondary organic aerosol (SOA) formation. Atmos. Chem. Phys. 2010, 10, 1052110539.

(27) Mekic, M.; Brigante, M.; Vione, D.; Gligorovski, S. Exploring the ionic strength effects on the photochemical degradation of pyruvic acid in atmospheric deliquescent aerosol particles. Atmos. Environ., 2018, 185, 237-242

(28) Shi, Q.; Pan, N.; Long, H.; Cui, D.; Guo, X.; Long, Y.; Chung, K. H.; Zhao, S.; Xu, C.; Hsu, C. S. Characterization of middle-temperature gasification coal tar. Part 3: Molecular composition of acidic compounds. Energy \& Fuels, 2012, 27(1), 108-117.

(29) Jiang, B.; Liang, Y.; Xu, C.; Zhang, J.; Hu, M.; Shi, Q. Polycyclic Aromatic Hydrocarbons (PAHs) in Ambient Aerosols from Beijing: Characterization of Low Volatile PAHs by Positive-Ion Atmospheric Pressure Photoionization (APPI) Coupled with Fourier Transform Ion Cyclotron Resonance. Environ. Sci. Technol. 2014, 48, 4716-4723.

(30) Frisch, M. J.; Trucks, G. W.; Schlegel, H. B.; Scuseria, G. E.; Robb, M. A.; Cheeseman, J. R.; Montgomery, J., J. A.; Vreven, T.; Kudin, K. N.; Burant, J. C.; Millam, J. M.; Iyengar, S. S.; 
Tomasi, J.; Barone, V.; Mennucci, B.; Cossi, M.; Scalmani, G.; Rega, N.; Petersson, G. A.; Nakatsuji, H.; Hada, M.; Ehara, M.; Toyota, K.; Fukuda, R.; Hasegawa, J.; Ishida, M.; Nakajima, T.; Honda, Y.; Kitao, O.; Nakai, H.; Klene, M.; Li, X.; Knox, J. E.; Hratchian, H. P.; Cross, J. B.; Bakken, V.; Adamo, C.; Jaramillo, J.; Gomperts, R.; Stratmann, R. E.; Yazyev, O.; Austin, A. J.; Cammi, R.; Pomelli, C.; Ochterski, J. W.; Ayala, P. Y.; Morokuma, K.; Voth, G. A.; Salvador, P.; Dannenberg, J. J.; Zakrzewski, V. G.; Dapprich, S.; Daniels, A. D.; Strain, M. C.; Farkas, O.; Malick, D. K.; Rabuck, A. D.; Raghavachari, K.; Foresman, J. B.; Ortiz, J. V.; Cui, Q.; Baboul, A. G.; Clifford, S.; Cioslowski, J.; Stefanov, B. B.; Liu, G.; Liashenko, A.; Piskorz, P.; Komaromi, I.; Martin, R. L.; Fox, D. J.; Keith, T.; Al-Laham, M. A.; Peng, C. Y.; Nanayakkara, A.; Challacombe, M.; Gill, P. M. W.; Johnson, B.; Chen, W.; Wong, M. W.; Gonzalez, C.; Pople, J. A. Gaussian 03 Revision D.01, Wallingford CT, 2004.

(31) Becke, A. D. Density-functional thermochemistry. III. The role of exact exchange $J$. Chem. Phys. 1993, 98, 5648-5652.

(32) Stephens, P. J.; Devlin, F. J.; Chabalowski, C. F.; Frisch, M. J. Ab Initio Calculation of Vibrational Absorption and Circular Dichroism Spectra Using Density Functional Force Fields. $J$. Phys. Chem. 1994, 98, 11623-11627.

(33) Dunning, T. H. Gaussian basis sets for use in correlated molecular calculations. I. The atoms boron through neon and hydrogen. J. Chem. Phys. 1989, 90, 1007-1023.

(34) Kendall, R. A.; Dunning, Jr., T. H.; Harrison, R. J. Electron Affinities of the First-Row Atoms Revisited. Systematic Basis Sets and Wave Functions. J. Chem. Phys. 1992, 96, 67966806.

(35) Barone. V.; Cossi, M. Quantum Calculation of Molecular Energies and Energy Gradients in Solution by a Conductor Solvent Model. J. Phys. Chem. A 1998, 102, 1995-2001.

(36) Cossi, M; Rega, N.; Scalmani, G.; Barone, V. Energies, Structures, and Electronic Properties of Molecules in Solution with the C-PCM Solvation Model. J. Comput. Chem. 2003, 24, 669-681.

(37) Takano, Y.; Houk, K.N. Benchmarking the Conductor-like Polarizable Continuum Model (CPCM) for Aqueous Solvation Free Energies of Neutral and Ionic Organic Molecules. J. Chem. Theory Comput. 2005, 1, 70-77.

(38) Guzman, M. I.; Colussi, A. J.; Hoffmann, M. R. Photoinduced oligomerization of aqueous pyruvic acid. J. Phys. Chem. A. 2006, 110 (10), 3619-3626.

(39) Griffith, E. C.; Carpenter, B. K.; Shoemaker, R. K.; Vaida, V. Photochemistry of aqueous pyruvic acid. PNAS. 2013, 110 (29), 11714-11719.

(40) Reed Harris, A. E.; Ervens, B.; Shoemaker, R. K.; Kroll, J. A.; Rapf, R. J.; Griffith, E. C.; Monod, A.; Vaida, V. Photochemical kinetics of pyruvic aid in aqueous solution. J. Phys. Chem. A. 2014, 118 (37), 8505-8516.

(41) Rapf, R. J.; Dooley, M. R.; Kappes, K.; Perkins, R. J.; Vaida, V. pH dependence of the Aqueous Photochemistry of $\alpha$-Keto Acids. J. Phys. Chem. A. 2017, 121 (44), 8368-8379.

(42) Eugene, A. J.; Guzman, M. I. Reactivity of Ketyl and Acetyl Radicals from Direct Solar Actinic Photolysis of Aqueous Pyruvic Acid. J. Phys. Chem. A. 2017, 121, 2924-2935. 
(43) Hsu, C. S.; Lobodin, V. V.; Rodgers, R. P.; McKenna, A. M.; Marshall, A. G. Compositional Boudnaries for Fossil Hydrocarbons. Energy Fuels. 2011, 25, 2174-2178.

(44) Islam, A.; Cho, Y.; Ahmed, A.; Kim, S. Data interpretation Methods for Petroleomics. Mass Spectrom. Lett. 2012, 3, 63-67.

(45) Cho, Y.; Ahmed, A.; Islam, A.; Kim, S. Developments in FT-ICR MS instrumentation, ionization techniques, and data interpretation methods for petroleomics. Mass Spectrom. Rev. 2014, 34, 248-263.

(46) Altieri, K. E.; Seitzinger, S. P.; Carlton, A. G.; Turpin, B. J.; Klein, G. C.; Marshall, A. G. Oligomers formed through in-cloud methylglyoxal reactions: Chemical composition, properties, and mechanisms investigated by ultra-high resolution FT-ICR mass spectrometry. Atmos. Environ. 2008, 42, 1476-1490.

(47) Van Wyngarden, A. L.; Pérez-Montaño, S.; Bui, J. V. H.; Li, E. S. W.; Nelson, T. E.; Ha, K. T.; Leong, L.; Iraci, L. T. Complex chemical composition of colored surface films formed from reactions of propanal in sulfuric acid at upper troposphere/lower stratosphere aerosol acidities. Atmos. Chem. Phys. 2015, 15, 4225-4239.

(48) George, I. J.; Abbatt, J. P. D. Heterogeneous oxidation of atmospheric aerosol particles by gas-phase radicals. Nature Chem. 2010, 2 (9), 713-722.

(49) Rossignol, S.; Aregahegn, K. Z.; Tinel, L.; Fine, L.; Noziere, B.; George, C. Glyoxal Induced Atmospheric Photosensitized Chemistry Leading to Organic Aerosol Growth. Environ. Sci. Technol. 2014, 48, 3218-3227.

(50) Sumner, A. J.; Woo, J. L.; McNeill, V.F. Model Analysis of Secondary Organic Aerosol Formation by Glyoxal in Laboratory Studies: The Case for Photoenhanced Chemistry. Environ. Sci. Technol. 2014, 48 (20), 11919-11925. 